86

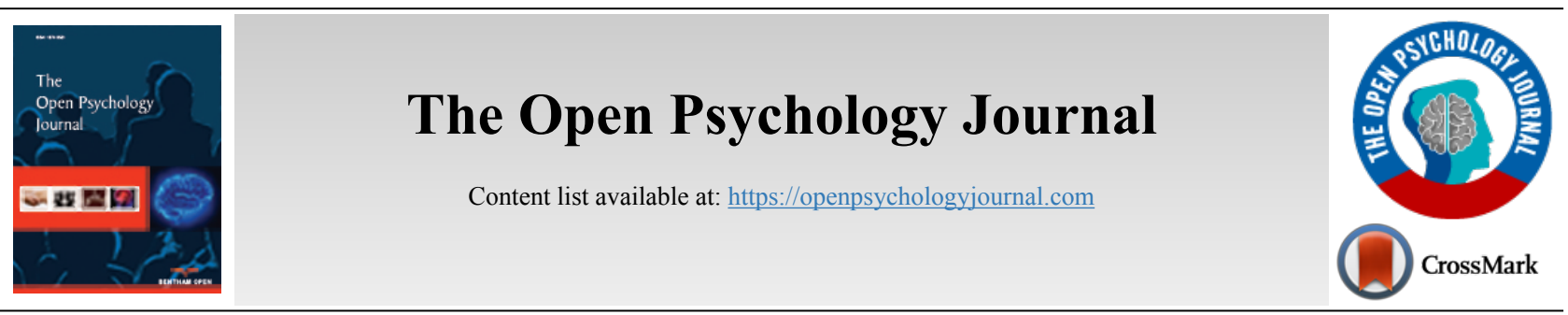

RESEARCH ARTICLE

\title{
Choice Shifts in School Disciplinary Decision Making: Analysis of Age Differences of Panel Members
}

Peter J.O. Aloka ${ }^{1, *}$

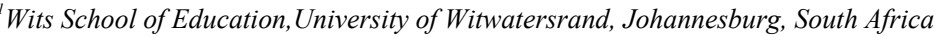

\begin{abstract}
:
Background:

Decision making is critical to each organization and it requires the ability to find a possible balance between risky and cautious decisions. The Kenyan secondary schools are mandated by the Ministry of Education to manage students' misbehaviors by the disciplinary panels.

Aim:

The present study investigated the choice shifts in disciplinary decision making in Kenyan secondary schools based on age groups of the panel members.

Methods:

The Quasi-Experimental Pretest-Posttest Design was adopted. The study targeted 360 teachers- members of disciplinary panels in 45 secondary schools in the Rongo sub-county of Kenya. A sample size of 78 members of disciplinary panels in 10 secondary schools was involved. This was $22 \%$ of the target population of members of disciplinary panels in the Rongo district. The choice shift in decisions was ascertained using the Modified Choice Dilemma Questionnaire. The validity of the tools was ensured by the expert judgment by two Kenyan psychologists, while the reliability was determined using the internal consistency method and an alpha of 0.695 was reported.

Results:

The results of the Multivariate Analysis Of Variance indicated that there were differences in choice shifts from the pre to post-disciplinary hearing decisions among the members of selected school disciplinary panels on the basis of their age groups $($ Wilk's Lambda $(\lambda)$ test: $F(12,188)=7.40, P$ $=0.000, P<0.05)$.

\section{Conclusion:}

It was concluded that the age of the members of disciplinary panels influenced the nature of choice shifts in decisions. It was recommended that principals should ensure that the membership of school disciplinary panels is broad-based.
\end{abstract}

Keywords: Choice shift, Disciplinary panels, Decision making, Age differences, Panel members, Modified choice dilemma questionnaire.

\begin{tabular}{l|l|l|l} 
Article History & Received: November 15, 2019 & Revised: March 09, 2020 & Accepted: March 30, 2020
\end{tabular}

\section{INTRODUCTION}

Decision making involves making a choice from a number of alternatives to achieve the desired result [1]. Duze CO [2] described decision making as the process by which leaders choose the best action or most preferred course of action among alternative sources of action with the purpose of solving the problem and achieving set goals effectively and efficiently.

\footnotetext{
* Address correspondence to this author at the Wits School of Education, University of Witwatersrand, Johannesburg, South Africa; Tel: +27117173098 , E-mail: jairopeteraloka@yahoo.com
}

Van Leijenhorst et al. [3] emphasized that decision making is the process of choosing between competing courses of action. Gulkan MG [4] emphasized that decision making is very important in successful organizational management. Pashiardis $P$ [5] added that there is an increasing level of teacher participation in decision making which makes schools respond to societal needs. Owens RG [6] emphasized that for participative decision-making to be effective, there is a need to bring the power and influence of both employees and the managers in an organization. Legesse D [7] highlighted the importance of groups in making decisions since groups can 
make higher-quality decisions than individuals because different ideas come together from different groups and the best from the given alternatives can be selected. Invancevich et al. [8] also emphasized that for groups to make effective decisions, the leadership must be effective in order to provide guidance in taking the best decisions. Mullins LJ [9] added that staff participation in organizational decision making increases the performance. Wilkinso A [10] summarized that the involvement of employees in decision making enhances the empowerment of employees with knowledge, skills and experience. Therefore, school principals need to embrace collective decision making in school management to enhance effective job performance.

\subsection{Group Decision Making in Schools}

Schools are organizations that are meant to provide the environment to ensure the education of students [11]. Caldwell and Spinks [12] emphasized that teachers need to be empowered by the various school boards of management in the acquisition of decision-making skills. Gemechu A [13] emphasized that school principals and teachers work together to implement decisions that affect the management of schools. Lightfoot SL [14] also indicated that teachers need to recognize their rights in effective decision making about students' issues in schools. According to Bullock A [15], young teachers could gain experience in decision making from the more experienced colleagues in school. Caldwell and Spinks [12] emphasized that school principals have the responsibility of supporting teachers in making quality decisions. Richardson and Placier [16] agreed that by encouraging teachers' participation in decision making in the manner of school restructuring, schools became more democratic organizations.

\subsection{Choice Shifts in Groups}

Group decisions are generally considered to be more beneficial as compared to decisions made by individuals. The dynamic interactions among group members always lead to a choice shift in decisions. The shifts in decisions could be either "risky" or "cautious" ones. Stoner JAF [17] defined risky shift as a situation where group members begin at a risk-averse level, and then finally become less risk-averse in their decisions. On the other hand, a cautious shift is a situation when group members begin with an average level of risktaking and then finally become more risk- averse in their final decisions. Stoner JAF [17]; and Kogan and Wallach [18] investigated the risky shift phenomenon, which changes in decisions when an individual is in a group as compared to when alone. The choice shift phenomenon explains that individuals in a group would make risky decisions which they cannot make as individuals [19]. Studies have also reported a cautious shift in decisions in groups. Nordøy F [20] indicated that group members were more cautious in their decisions. Other studies carried out by Fraser et al. [21]; and by Clement and Sullivan [22], have all reported that groups mostly make more cautious decisions as compared to individually made decisions. Holt and Laury [23] also agreed that groups make risk aversive decisions.

\subsection{Kenyan School Disciplinary Panels.}

Students' behavior problems have been on the rise in Kenyan schools. Schools are mandated by the Kenyan Ministry of Education to manage students' misbehaviors by the disciplinary panels which comprise of selected teachers depending on years of experience and departments [24].The school disciplinary panels operate as small social groups in order to arrive at consensus decisions. School disciplinary decisions are believed to be collective in nature and are thus believed to be more superior to individually made decisions. In addition, group decision making makes the most of the combined individual abilities, knowledge and expertise of the group members [25]. The dynamic interactions result into panel decisions that are employed to manage students' behaviour problems. The disciplinary panel decisions concerning behaviour problems of students are made after the panel members have studied the case at hand well enough and sought the opinions of other group members, considering the factors including the professional demands and school management expectations [24]. The school disciplinary panels operate as small social groups. Do the dynamics in the panels lead to choice shifts in decisions on the basis of the age of the panel members? Thus, the study investigated the choice shifts in disciplinary decision making in Kenyan secondary schools on the basis of the age of the panel members.

\section{Literature Review}

This study was guided by the Socioemotional Selectivity Theory (SST). According to this theory, in most cases when there is limited time in performing a task, people are more likely to pursue goals that are emotion-orientated rather than knowledge-orientated. Charles et al. [26], reiterated that the theory of the study of emotion and aging argues that people prioritize different kinds of goals as they perceive future time differently. The older adults may maintain their emotional well-being by selectively pursuing emotionally meaningful goals and downplaying knowledge-related goals as they perceive their future time as increasingly limited. Such a shift in goals has impact on value, preference, and decision making [27]. For example, compared with younger adults, older adults prefer to interact with emotionally close partners over peripheral social partners. Previous studies have been done on the influence of age on choice shifts in decision making in experimental setups and other natural settings. The study by Defoe et al. [28] reported age differences in choice shifts in decision making as the adolescents made risks decisions while the adults were risk aversive in their decisions. Sproten et al. [29] revealed that the adults being more risk-averse while the youths are always risky in their decisions. On the contrary, the study by Mata et al. [30] reported that older adults were more risk-seeking as compared to younger adults who were more risk-averse when making decisions. Cavanagh et al. [31] indicated that among seniors, increasing age was associated with greater reward-related risk taking hence most decisions were risky. Wood MM [32] reported that older adults are more cautious in their decisions as compared to the younger adults who make riskier decisions. Defoe IN, SemonDubas J and Romer D [28] indicated that adolescents engage in more risky decision-making than adults who tend to be more risk aversive 
in their decisions. On the other hand, Pollock J [33]. reported that age was not a significant predictor of any of the domains of risky decision making. Neeltje et al. [34] indicated that there were no age differences in risk-attitude in decision making. The study by Van Leijenhorst et al. [3] reported that adults had increased risk-taking in their decisions when there was a reward.

The study by Levin et al. [35] also reported that children made more risky choices as compared to the adults when risky choices were disadvantageous. Watanabe and Shibutani [36] indicated that there were no age differences in decision making. Thus, both the young and adults showed an increasingly higher risk $\square$ aversive tendency corresponding to the monotonically increased number of human lives at risk. Westbrook et al. [37] reported that there were no differences in choice shifts in decisions on the basis of ages of participants. The study by Rolison et al. [38] revealed that risk-taking reduces in older age, but it increases slightly from young to middle age. Rolison et al. [39] also agreed that younger adults were more willing to take greater risks, while older adults were more cautious. In their study of lottery, Albert and Duffy [40] indicated that older adults were more risk-averse than young people. Weller et al. [41] reported that older adults are more risk-averse in their decisions as compared to the youths.

Bonem et al. [42] reported that, in the health and ethical domains, youths make more risky decisions as compared with adults who make cautious decisions. However, on the social domains, the adults make cautious decisions while the youths are risky in their decisions. In an experimental study of lotterypair types, Kellen et al. [43] reported that older adults appear to be more risk- seeking than younger adults in making decisions. In Nigeria [44], study reported age differences in risky decisions. The study reported that younger women were more risky in their decisions on choice of contraceptive as compared to older women. Most of the previous studies reviewed have been done on choice shifts in decisions in other settings like hospitals, experimental setups and lottery games but none was found to have been carried out in educational settings. The studies indicated the evidence of choice shifts in the decisions of small groups. The school disciplinary panels operate as small groups and are thus prone to dynamics within small groups. Therefore, the present study investigated the choice shifts in disciplinary decision making in Kenyan secondary schools on the basis of the age of the panel members.

The null hypothesis was thus stated as follows:

$\mathrm{H}_{0}$ :There are no statistically significant age differences, in the choice shifts from pre to post-disciplinary hearing decisions among members of the disciplinary panels in Kenyan secondary schools

\section{MATERIALS AND METHODS}

\subsection{Research Design \& Participants}

The study was guided by the Quasi-Experimental PretestPosttest Design. According to Harris et al. [45], in this design, the dependent variable is measured once before the treatment is implemented and once after it is implemented. In this design, the subjects involved are given a pretest measurement before the disciplinary hearing, followed by an intervention and finally, a posttest measurement after deliberations. The study population comprised of 360 teachers who are members of disciplinary panels in 45 secondary schools in the Rongo subcounty of Kenya. A sample size of 78 members of the disciplinary panels was obtained from 10 secondary schools using the stratified random sampling. Each of the disciplinary panels had an average of between 7-8 members. This was $22 \%$ of the target population of the members of the disciplinary panels in the district. The sample size was considered appropriate because power analysis which recommended that at least $20 \%$ of the target population to be taken as the sample of the study was used in the selection of the sample size.

\subsection{Tools}

Quantitative data was obtained from the Modified Choice Dilemma Questionnaire (MCDQ) which was adapted from the original Choice Dilemma Questionnaire developed by Stoner in 1961 [Ronay and Kim] [46]. According to Wallach et al. [47], the Choice Dilemma Questionnaire is a research instrument used to measure an individual's choice of either risky or cautious decisions. Respondents are presented with a series of scenarios involving a course of action that might or might not have certain benefits; they then indicate what the odds of success would have to be before they would recommend the choice of their decisions. According to Stoner JAF [17], the CDQ is a self-administered questionnaire which can be used with participants aged eight years old to adult age (21 years and above). The responses to MCDQ are coded along a continuum scale of acceptable probabilities adapted from the Stoner's choice dilemmas [17, 48]. Each Choice-Dilemma was accompanied by the standard instructions to choose between odds of 1, 2, 3, 4, 5, 6, 7, 8 or 9 chances in the lowest odds of success acceptable in order to recommend an opinion concerning an offending behavior or violation [48]. The selection of 7 or 9 in 10 chances option in a decision suggests the more likely risky decision. The selection of 1 or 3 in 10 chances option in a decision suggests the more likely cautious decision. Thus, the MCDQ helped to assess the choice shifts from pre-post disciplinary hearing decisions among the panel members. The face and content validity of the Modified Choice Dilemma Questionnaire was ensured by the expert judgment by two Kenyan psychologists who are experts in group dynamics. The reliability of the Modified Choice Dilemma Questionnaire was determined using the internal consistency method and an alpha of 0.695 was reported. This was acceptable because a minimum of 0.6 is recommended [49].

\subsection{Procedure}

Permission to carry out the study was first obtained from the National Council for Science, Technology \& Innovation, Kenya. Thereafter, the researcher obtained permission from Rongo Sub-county Education and then proceeded to the 10 selected secondary schools. The researcher upon reaching the selected school made a request to the school principal to give permission to collect data during a disciplinary panel meeting handling students' behavior problems. On the day of the disciplinary hearing meeting, the researcher was introduced to the panel members by the deputy principal who assumes the 
chair position of the group in the Kenyan context. The researcher explained the purpose of the study and assured the respondents that the data would be used for research purposes only. The researcher then issued the Modified Choice Dilemma Questionnaire to the panel members. The questionnaire was completed twice by the same participants. The first one was just before the disciplinary hearing meeting to obtain each panel member's decision on the disciplinary case presented to them each of the four factors associated with the discipline problem. This helped to obtain pre-group response scores from each respondent. The second one was after the disciplinary hearing, where the participants were issued with fresh but similar Modified Choice Dilemma Questionnaires to complete again to indicate the decision after the disciplinary hearing. This helped to obtain the post-group response scores of each respondent. The disciplinary meetings took an average of one hour for each case presented.

\subsection{Data Analysis}

Data analysis involved comparing the pre-group and postgroup response scores for each of the study participants to ascertain the shifts in decisions. Since the study investigated the age differences in the choice shifts; the Multivariate Analysis Of Variance (MANOVA) was used. The Multivariate analysis of variance is used when there are two or more dependent variables in the study. There were four aspects in which school disciplinary decisions were made. From the MANOVA results, the Wilk's lambda test results were used because of its strength among the other tests such as Pillai's trace test, Hotellings, and Roy's largest root test [50]. The Multivariate analysis of variance was used to analyze data because the age of disciplinary panel members was grouped into four categories and the dependent variables were four aspects on which disciplinary decisions were made. The multiple analyses of variance (MANOVA) is a statistical test that captures the effects of multiple independent variables on more than one dependent variable.

\section{RESULTS}

The null hypothesis was stated as follows:

$\mathrm{H}^{\mathrm{o}}$ There are no statistically significant age differences, in the choice shifts from pre to post- disciplinary hearing decisions among members of the disciplinary panels in Kenyan secondary schools.

The age of members of disciplinary panel was categorized into four groups $(20-29$ years $(\mathrm{n}=21), 30-39$ years $(\mathrm{n}=28)$, $40-49$ years $(n=14)$, and $50-59$ years $(n=15)$. The pre-group and post-group disciplinary hearing response scores on the MCDQ were obtained for each participant in the different age groups. Thereafter, the estimated mean differences in response scores for each age group of participants were found. The results are presented in Fig. (1-4). The results from descriptive statistics presented in Table 1 indicate that the panel members of the age group 20-29 years had the greatest shifts from pre to post-disciplinary hearing decisions as compared to the other panel members in the other age groups. Most of the participants in the age group 50-59 years had the least choice shift in the pre and post-disciplinary hearing decisions. The greatest shift was with respect to the Behaviour characteristics of the offender (Fig. 2). Therefore, from the descriptive statistical analysis, it was evident that there were age differences in the choice shifts from the pre to post-disciplinary hearing decisions.

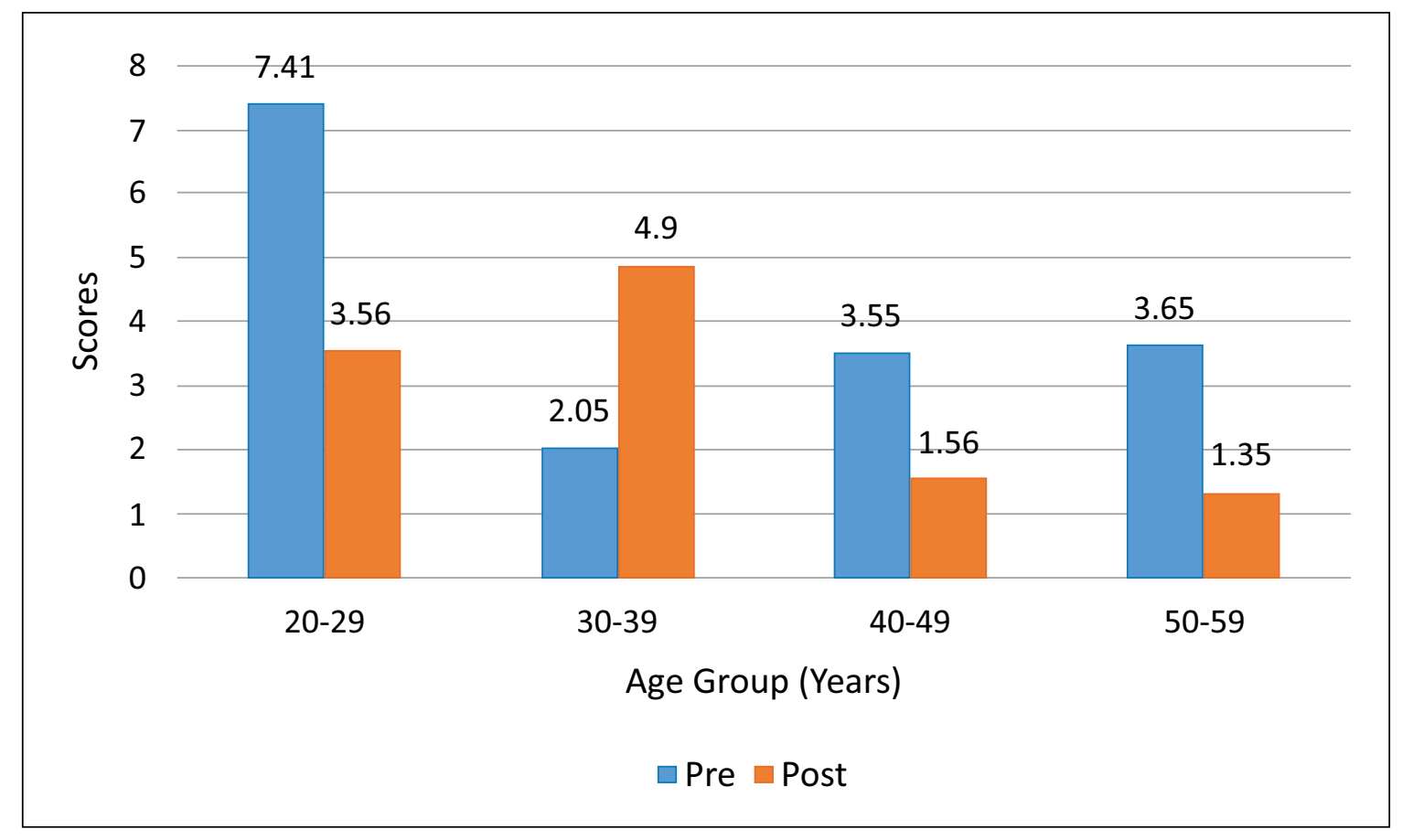

Fig. (1). Pre and Post group Response Scores on the Type of Disciplinary Problem based on Age of Panel Members. 


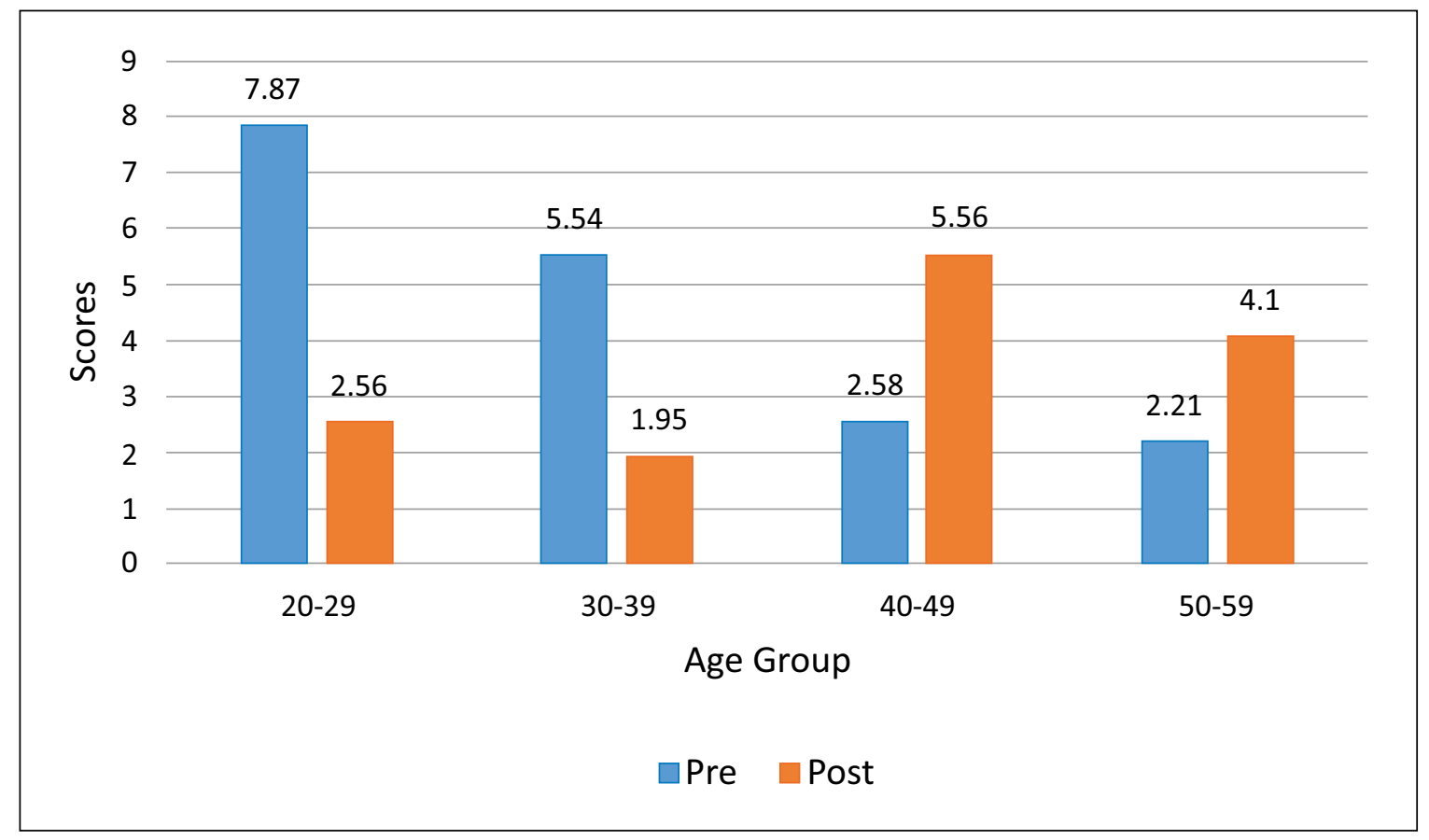

Fig. (2). Pre and Post group Response Scores on the Behaviour characteristics of the offender based on Age of Panel Members.

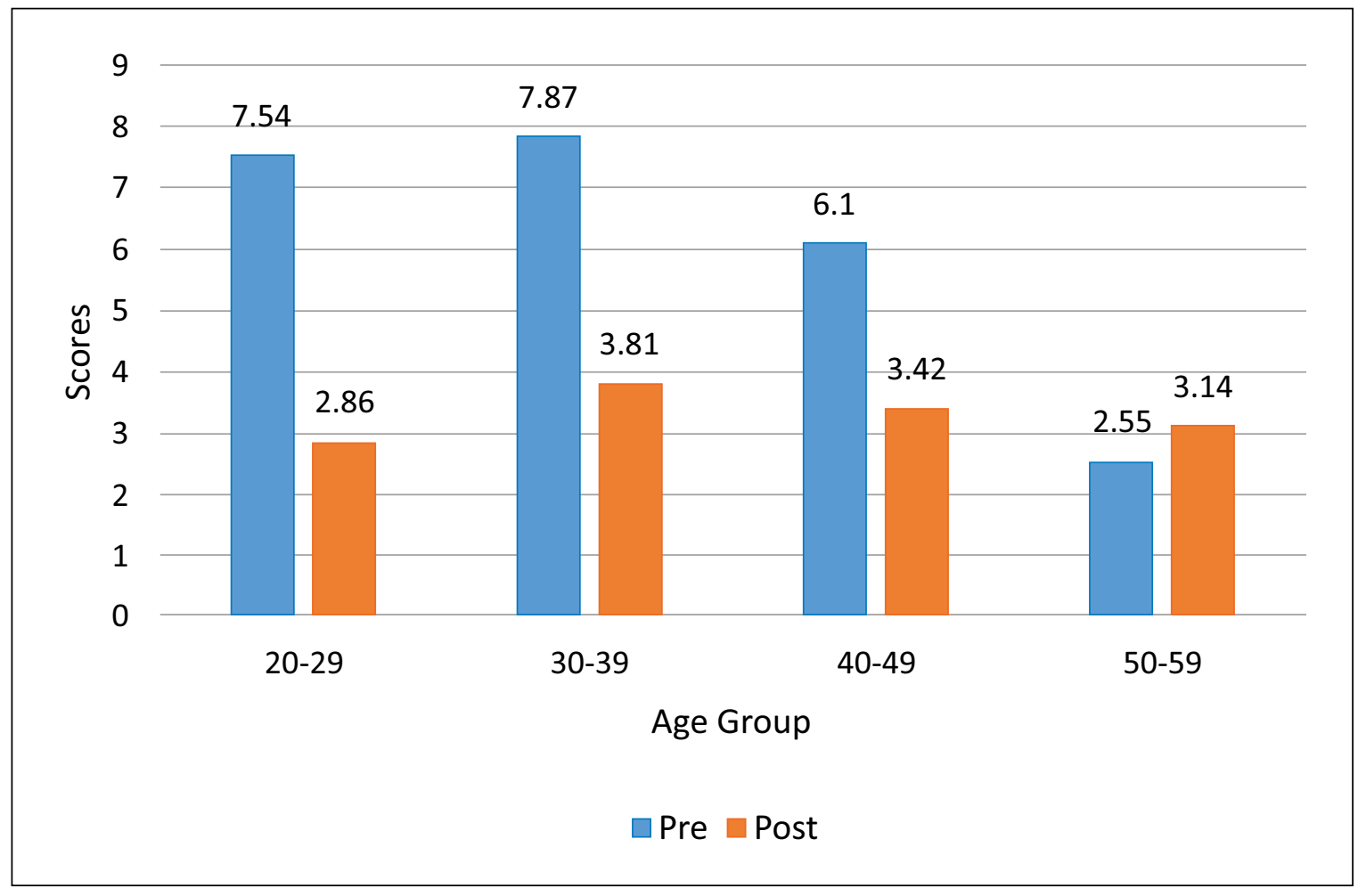

Fig. (3). Pre and Post group Response Scores on the Effect on the Disciplinary Tone of the School based on Age of Panel Members. 


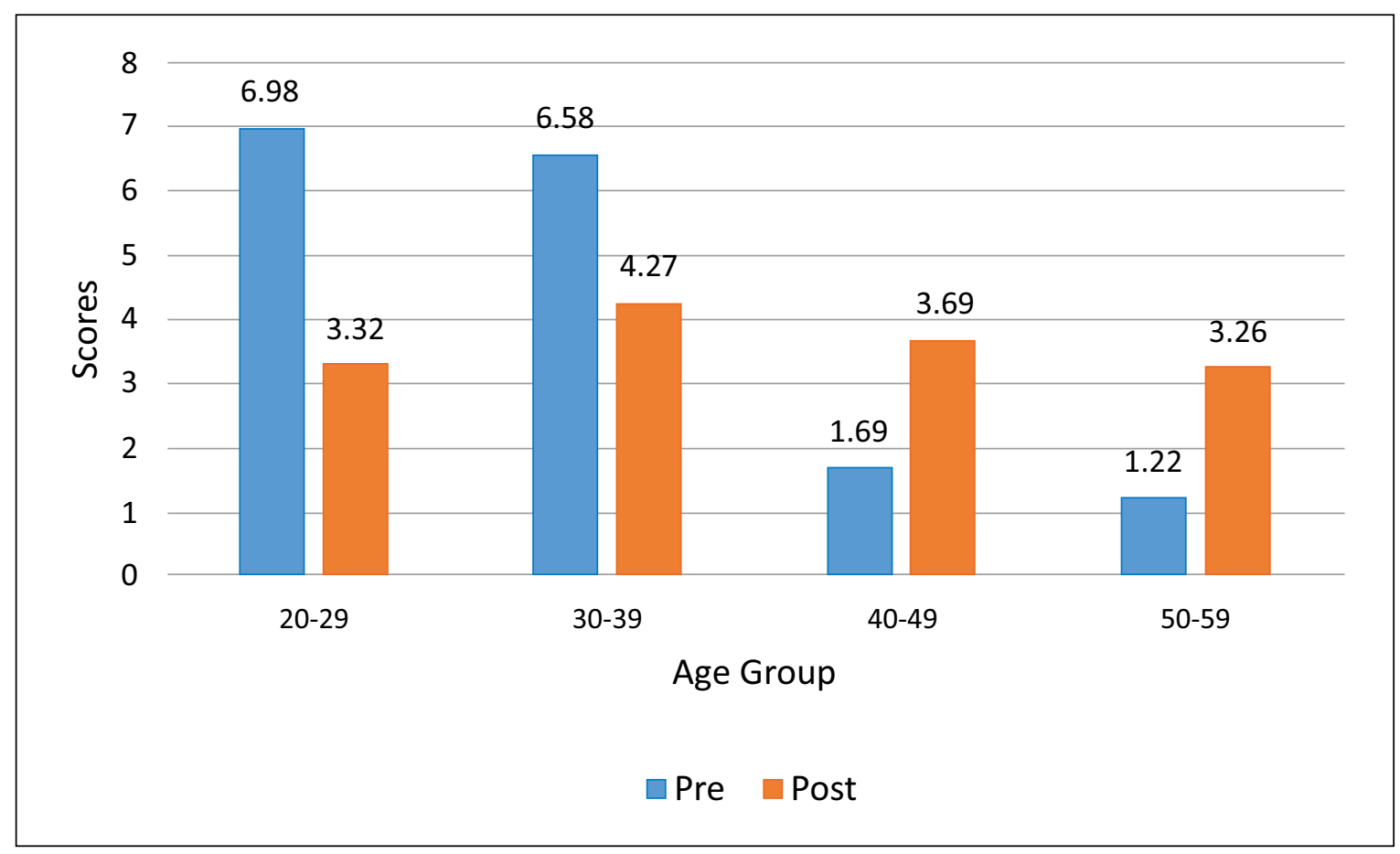

Fig. (4). Pre and Post group Response Scores on the effects of Disciplinary Problem on the Victim based on Age of Panel Members.

Table 1. Pre and Post group response scores and estimated choice shifts in decisions on the bases of the age of panel members.

\begin{tabular}{|c|c|c|c|c|c|c|}
\hline Factors Associated With The Problems & Age Groups (yrs) & $\mathbf{N}$ & $\begin{array}{l}\text { Pre- Group Response } \\
\text { Score }\end{array}$ & $\begin{array}{c}\text { Post- Group Response } \\
\text { Score }\end{array}$ & $\begin{array}{c}\text { Estimated Differences } \\
\text { Between the } \\
\text { Pre and Post - Group } \\
\text { Scores } \\
\end{array}$ & \begin{tabular}{|c|} 
Std \\
Error
\end{tabular} \\
\hline \multirow[t]{4}{*}{ The type of disciplinary problem } & $20-29$ & 21 & 7.41 & 3.56 & 4.45 & 0.412 \\
\hline & $30-39$ & 28 & 6.95 & 2.05 & 4.90 & 0.520 \\
\hline & $40-49$ & 14 & 5.11 & 3.55 & 1.56 & 0.245 \\
\hline & $50-59$ & 15 & 2.30 & 3.65 & 1.35 & 0.212 \\
\hline \multirow[t]{4}{*}{ Behaviour characteristics of the offender } & $20-29$ & 21 & 7.87 & 2.56 & 5.31 & 0.754 \\
\hline & $30-39$ & 28 & 5.54 & 1.95 & 3.59 & 0.652 \\
\hline & $40-49$ & 14 & 2.58 & 5.56 & 2.40 & 0.562 \\
\hline & $50-59$ & 15 & 2.21 & 4.10 & 1.89 & 0.423 \\
\hline \multirow{4}{*}{$\begin{array}{l}\text { The effect of the problem on the } \\
\text { disciplinary tone of the school }\end{array}$} & $20-29$ & 21 & 7.54 & 2.36 & 5.18 & \begin{tabular}{|l|l|} 
\\
\end{tabular} \\
\hline & $30-39$ & 28 & 7.87 & 3.81 & 4.06 & 0.654 \\
\hline & $40-49$ & 14 & 6.10 & 3.42 & 2.60 & 0.524 \\
\hline & 50-59 & 15 & 2.55 & 3.14 & 0.59 & 0.230 \\
\hline \multirow{4}{*}{$\begin{array}{c}\text { The effects of the disciplinary problem on } \\
\text { the victim }\end{array}$} & $20-29$ & 21 & 6.98 & 3.32 & 3.66 & 0.575 \\
\hline & 30-39 & 28 & 6.58 & 4.27 & 2.31 & 0.533 \\
\hline & $40-49$ & 14 & 1.69 & 3.69 & 2.00 & 0.521 \\
\hline & 50-59 & 15 & 1.22 & 3.26 & 2.04 & \begin{tabular}{|l|l|} 
& 0.458 \\
\end{tabular} \\
\hline
\end{tabular}

To ascertain whether or not there were significant age differences in choice shifts on the basis of age groups, a Multivariate Analysis of Variance (MANOVA) test was performed. The Wilk's Lambda $(\lambda)$ test: $F(12,188)=7.40, P$ $=0.000, P<0.05)$ was reported from the results presented in Table 2. Since the p-value obtained (0.05) was less than the pvalue 0.00 , the null hypothesis which stated that "there are no statistically age significant differences, in the choice shifts from pre to post-disciplinary hearing decisions among panel members", was rejected. Therefore, it can be concluded that there are significant age differences in choice shifts from the pre to post-disciplinary hearing decisions among the members of selected school disciplinary panels.

Since the MANOVA results (Wilk's Lambda $(\lambda)$ test) reported significant age differences in the choice shifts among 
disciplinary panel members; further data analysis was performed to locate exactly where the differences lie. To do this, the Scheffe's Post Hoc Multiple Comparisons test was used. The Scheffe's Post Hoc results presented in Table 3 indicated that panel members of the age groups 40-49 years and 50-59 years experienced little choice shifts in their pre to post-disciplinary hearing decisions, as compared to those in 20-29 years and 30-39 years of age categories who experienced large choice shifts in their decisions. Thus, it can be concluded that young panel members were influenced significantly by the factors in the dynamic interactions among members of the panels during a disciplinary hearing, while the older ones were to a little extent. Therefore, it meant that the age of panel members influenced choice shifts in decisions.

\section{DISCUSSION}

The aim of the study was to investigate age differences of the panel members in the choice shift in disciplinary decision making in Kenyan secondary schools. The findings indicated that there were significant age differences in the choice shifts from the pre to post-disciplinary hearing decisions among the members of selected school disciplinary panels. Older teachers experienced little choice shifts in their disciplinary decisions; an indication that they made cautious decisions. On the other hand, younger teachers had larger choice shifts in their pre-post group disciplinary decisions; an indication that they made risky decisions on the disciplinary problems presented. This finding agrees with the study by Defoe et al. [51], which reported that adolescents made risks decisions while the adults were risk aversive in their decisions. Similarly, Sproten et al. [29] revealed that the adults being more risk-averse while the youths are always risky in their decisions. In addition, Wood MM [32]. reported that older adults are more cautious in their decisions as compared to the younger adults who made riskier decisions. The study by Rolison et al. [38] revealed that risktaking reduces in older age, but it increases slightly from young to middle age. Rolison et al [39] also agreed that younger adults were more willing to take greater risks, while older adults were more cautious. In their study of lottery, Albert and Duffy [40] indicated that older adults were more risk-averse than young people. Weller et al. [41] reported that older adults are more risk-averse in their decisions as compared to the youths. Bonem et al. [42] study concurred that youths make more risky decisions as compared with adults who make cautious decisions.

On the contrary, Mata et al. [30] study reported that older adults were more risk-seeking as compared to younger adults who were more risk-averse when making decisions. Similarly, Van Leijenhorst et al. [3] also reported that adults had increased risk-taking in their decisions when there was a reward. Cavanagh et al. [31] indicated that among seniors, increasing age was associated with greater reward-related risktaking hence most decisions were risky. On the other hand, Pollock J [33] reported that age was not a significant predictor of any of the domains of risky decision making. The study by Watanabe and Shibutani [36] also indicated that there were no age differences in decision making. Neeltje et al. [34] indicated that there were no age differences in risk-attitude in decision making. Westbrook et al. [37] reported that there were no differences in choice shifts in decisions on the basis of the age of participants.

Table 2. MANOVA results of the pre and post-disciplinary hearing shifts in decisions among panel members on the basis of age groups.

\begin{tabular}{|c|l|l|l|l|l|}
\hline Effect & Value & F & Hypotheses Df & Error Df & Sig. \\
\hline Pillai's Trace & 0.718 & 5.738 & 12.00 & 219.00 & $0.000^{*}$ \\
\hline Hotelling's Trace & 1.570 & 9.117 & 12.00 & 209.00 & $0.000^{*}$ \\
\hline Roy's Largest Root & 1.247 & 2.605 & 4.00 & 73.00 & $0.000^{*}$ \\
\hline Wilk's Lamda & 0.360 & 7.400 & 12.00 & 188.00 & $0.000^{*}$ \\
\hline
\end{tabular}

Table 3. Scheffe's Post Hoc results on pre and post-disciplinary hearing choice shifts in decisions on the basis of panel members' age groups.

\begin{tabular}{|c|c|c|c|c|c|}
\hline Dependent Variable & (I)Age Groups & (J) Age Groups & $\begin{array}{c}\text { Mean Differences in Choice Shifts } \\
\text { in Decisions }\end{array}$ & Std. Error & Sig. \\
\hline & \multirow[t]{3}{*}{$20-29$ years } & $30-39$ & 0.45 & 0.422 & 0.365 \\
\hline & & $40-49$ & 2.89 & 0.526 & $0.000^{*}$ \\
\hline & & $50-59$ & 3.10 & 0.722 & $0.000^{*}$ \\
\hline \multirow[t]{3}{*}{ Behaviour characteristics of the offender } & \multirow{3}{*}{$\begin{array}{l}30-39 \\
\text { years }\end{array}$} & $20-29$ & 1.72 & 0.263 & $0.019^{*}$ \\
\hline & & $40-49$ & 2.91 & 0.422 & $0.000^{*}$ \\
\hline & & $50-59$ & 1.70 & 0.652 & $0.023^{*}$ \\
\hline \multirow{3}{*}{$\begin{array}{l}\text { The effect of the problem on the disciplinary tone of the } \\
\text { school }\end{array}$} & \multirow[t]{3}{*}{$40-49$ years } & $20-29$ & 1.66 & 0.563 & 0.035 \\
\hline & & $30-39$ & 0.31 & 0.524 & 0.754 \\
\hline & & $50-59$ & 0.04 & 0.632 & 0.958 \\
\hline
\end{tabular}


(Table $\square$ ) contd......

\begin{tabular}{|c|c|c|c|c|c|}
\hline \multirow[t]{3}{*}{ The effects of the disciplinary problem on the victim } & \multirow[t]{3}{*}{$50-59$ years } & $20-29$ & 4.59 & 0.410 & $0.000 *$ \\
\hline & & $30-39$ & 3.47 & 0.220 & $0.000 *$ \\
\hline & & $40-49$ & 1.01 & 0.426 & 0.065 \\
\hline
\end{tabular}

\section{CONCLUSION}

The study concludes that the age of panel members determines the nature of disciplinary decisions in group deliberations. Older panel members tend to make more cautious decisions while the young teachers who are panel members shifted towards risky decisions. The implication of this finding is that young teachers were not tolerant of certain students' behaviour tendencies and that probably they were more responsive to the dynamics of the disciplinary panel group deliberations. The older teachers were tolerant of the students' behaviour tendencies or were not very responsive to the dynamics of the panel group meetings. Concerning students' disciplinary problems, some cases might require risky decisions due to their effect on school tone, while there are disciplinary problems that might need cautious decisions. Therefore, it is recommended that school principals should ensure that the school disciplinary panels are broad-based in their composition to have members of different age categories. This is because there are disciplinary issues that would require risky decisions from young panel members and at the same time certain students' behavior problems might require cautious decisions from the older panel members. One of the study limitations was that the Modified Choice Dilemma Questionnaire was adapted to the Kenyan context and, no doubt, yielded valuable information for the study. However, a wholly Kenyan constructed instrument probably would have yielded different information and by doing so, improve the findings of the study. Future research could look into the effects of cautious and risky decisions on the behaviour of students who appear at disciplinary hearings.

\section{ETHICS APPROVAL AND CONSENT TO PARTICIPATE}

This study was approved by the University of the Western Cape Research Ethics Committee, South Africa under ethical approval number 10/8/36.

\section{HUMAN AND ANIMAL RIGHTS}

Not applicable.

\section{CONSENT FOR PUBLICATION}

Informed consent was taken from all the participants when they were enrolled.

\section{AVAILABILITY OF DATA AND MATERIALS}

The data that support the findings of this study are available from the corresponding author [P.A] upon request.

\section{FUNDING}

None.

\section{CONFLICT OF INTEREST}

The author declares no conflict of interest, financial or otherwise.

\section{ACKNOWLEDGEMENTS}

Declared none.

\section{REFERENCES}

[1] Eisenfuhr F. Decision making. New York, NY: Springer 2011

[2] Duze CO. Students' and teachers' participation in decision-making and impact on school work and school internal discipline in Nigeria. International Multi-Disciplinary Journal 2011; 5(2): 200-14. [http://dx.doi.org/10.4314/afrrev.v5i2.67316]

[3] Van Leijenhorst L, Westenberg PM, Crone EA. A developmental study of risky decisions on the cake gambling task: Age and gender analyses of probability estimation and reward evaluation. Dev Neuropsychol 2008; 33(2): 179-96.

[http://dx.doi.org/10.1080/87565640701884287] [PMID: 18443976]

[4] Gulkan MG. Participating in the decision making process in educational management (The Ministry of National Education Case). World Appl Sci J 2008; 3(6): 939-44.

[5] Pashiardis P. Teachers' participation in decision-making. Int J Educ Manag 1994; 8(5): 1417.

[http://dx.doi.org/10.1108/09513549410065693]

[6] Owens RG. Organization behavior in education. Boston: Ally and Bacon 1998.

[7] Legesse D. Trainers' participation in decision-making in selected governmental technical vocational and training college of Addis Ababa MA Thesis in Management of Vocational Education, Department of Education. Addis Ababa University. 2008.2008.

[8] Invancevich J, Konopaske R, Matteson M. Organizational behavior and management. 7th ed. New York: McGraw Hill Companies, Inc 2005 .

[9] Mullins LJ. Management and organizational behaviour. 7th ed. New Deihi: Prentice - Hall 2004.

[10] Wilkinso A.

[11] Kamat HD. Democratic discipline in school. New Delhi: Common Wealth publisher 2008.

[12] Caldwell BJ, Spinks JM. Leading the self-managing school. London: Falmer Press 1992.

[13] Gemechu A. The practices of teachers' involvement in decisionmaking in government secondary schools of Jimma Town. MA Thesis, Department of Educational Planning and Management Jimma University. 2014.

[14] Lightfoot SL. On goodness in schools: Themes of empowerment. Peabody J Educ 1986; 63(3): 9-28. [http://dx.doi.org/10.1080/01619568609538522]

[15] Bullock A. Teacher participation in school decision making. Camb J Educ 2006; 10(1): 21-8.

[http://dx.doi.org/10.1080/0305764800100104]

[16] Richardson V, Placier P. Teacher change Handbook of research on teaching. 4th ed. New York: AERA 2001; pp. 905-47.

[17] Stoner JAF. A comparison of individual and group decisions involving risk. Msc Thesis, School of Industrial Management, Massachutes Institute of Technology . 1961.

[18] Kogan N, Wallach MA. Risk-Taking: A Study in Cognition and Personality. New York: Holt, Rinehart, Winston 1964.

[19] Sorrentino RM, Hewitt EC, Raso-Knott PA. Risk-taking in games of chance and skill: individual differences in affective and information value. J Pers Soc Psychol 1992; 62: 522-33. [http://dx.doi.org/10.1037/0022-3514.62.3.522]

[20] Nordøy F. Group interaction in decision-making under risk. Published Msc Thesis, School of Industrial Management, Massachutes Institute of Technology. 1962.

[21] Fraser C, Gouge CM, Billig M. Risky-shifts, cautious-shifts and group polarization. Eur J Soc Psychol 1970; 1: 7-30. [http://dx.doi.org/10.1002/ejsp.2420010103]

[22] Clement DE, Sullivan DW. No risky-shift effect with real groups and real risks. Psychoriomlc Science 1970; 18: 243-5. [http://dx.doi.org/10.3758/BF03335759]

[23] Holt CA, Laury SK. Risk aversion and incentive effects: New data 
without order effects. Am Econ Rev 2005; 95(3): 897-901 [http://dx.doi.org/10.1257/0002828054201459]

[24] Aloka PJO. Group polarization in decision making: A study of selected secondary school disciplinary panels in Rongo district of Kenya. PhD thesis, Department of Educational Psychology, University of the Western Cape. 2012.

[25] Boroushaki S, Malczewski J. Measuring consensus for collaborative decision-making: A GIS-based approach. Comput Environ Urban Syst 2010; 34(4): 322-32.

[http://dx.doi.org/10.1016/j.compenvurbsys.2010.02.006]

[26] Charles ST, Mather M, Carstensen LL. Aging and emotional memory: the forgettable nature of negative images for older adults. J Exp Psychol Gen 2003; 132(2): 310-24.

[http://dx.doi.org/10.1037/0096-3445.132.2.310] [PMID: 12825643]

[27] Carstensen LL. The influence of a sense of time on human development. Science 2006; 312(5782): 1913-5. [http://dx.doi.org/10.1126/science.1127488] [PMID: 16809530]

[28] Defoe IN. SemonDubas J, Romer D. Heightened adolescent risktaking? Insights from lab studies on age differences in decisionmaking. Policy Insights Behav Brain Sci 2019; 6(1): 56-63. [http://dx.doi.org/10.1177/2372732218801037]

[29] Sproten AN, Diener C, Fiebach CJ, et al. Decision making and age: Factors influencing decision making under uncertainty. J Behav Exp Economics, Elsevier 2018; 76(C): 43-54.

[http://dx.doi.org/10.1016/j.socec.2018.07.002]

[30] Mata R, Josef AK, Samanez-Larkin GR, Hertwig R. Age differences in risky choice: a meta-analysis. Ann N Y Acad Sci 2011; 1235 : 18-29.

[http://dx.doi.org/10.1111/j.1749-6632.2011.06200.x] [PMID: 22023565]

[31] Cavanagh JF, Neville D, Cohen MX, et al. Individual differences in risky decision-making among seniors reflect increased reward sensitivity. Front Neurosci 2012; 6: 111.

[http://dx.doi.org/10.3389/fnins.2012.00111] [PMID: 22822391]

[32] Wood MM. Age differences in risky decision making: the effects of priming, personality, and working memory. Master of Arts Thesis, The University of Alabama. 2017.

[33] Pollock J. Modeling age differences in risky decision making. PhD Thesis, University of Akron. 2016.

[34] Neeltje E, Blankenstein CEA. Dealing with uncertainty: Testing riskand ambiguity-attitude across adolescence Developmental Neuropsychology 2016; 41:1-2: 77-92.

[http://dx.doi.org/10.1080/87565641.2016.1158265]

[35] Levin IP, Weller JA, Pederson AA, et al. Age-related differences in adaptive decision making: Sensitivity to expected value in risky choice. Society for Judgment and Decision Making 2007; 2: 225-33.

[36] Watanabe S, Shibutani H. Aging and decision making: Differences in susceptibility to the risky $\square$ choice framing effect between older and younger adults in Japan. Jpn Psychol Res 2010; 52(3): 163-74. [http://dx.doi.org/10.1111/j.1468-5884.2010.00432.x]

[37] Westbrook SR, Hankosky ER, Dwyer MR, Gulley JM. Age and sex differences in behavioral flexibility, sensitivity to reward value, and risky decision-making. Behav Neurosci 2018; 132(2): 75-87.

[http://dx.doi.org/10.1037/bne0000235] [PMID: 29481101]

[38] Rolison JJ. Risk-taking differences across the adult life Span: A question of age and domain The J of Geront: Series B 2014; 69(6): 870-80.

[http://dx.doi.org/10.1093/geronb/gbt081]

[39] Rolison JJ, Hanoch Y, Wood S. Risky decision making in younger and older adults: the role of learning. Psychol Aging 2012; 27(1): 129-40. [http://dx.doi.org/10.1037/a0024689] [PMID: 21767022]

[40] Albert SM, Duffy J. Differences in risk aversion between young and older adults. Neurosci Neuroecon 2012; 2012(1): 3-9. [http://dx.doi.org/10.2147/NAN.S27184] [PMID: 24319671]

[41] Weller JA, King ML, Figner B, Denburg NL. Information use in risky decision making: Do age differences depend on affective context? Psychol Aging 2019; 34(7): 1005-20.

[http://dx.doi.org/10.1037/pag0000397] [PMID: 31580088]

[42] Bonem EM, Ellsworth PC, Gonzalez R. Age differences in risk: Perceptions, intentions and domains. J Behav Decis Making 2015; 28(4): 212-8.

[http://dx.doi.org/10.1002/bdm.1848]

[43] Kellen D, Mata R, Davis-Stober CP. Individual classification of strong risk attitudes: An application across lottery types and age groups. Psychon Bull Rev 2017; 24(4): 1341-9.

[http://dx.doi.org/10.3758/s13423-016-1212-5] [PMID: 28063131]

[44] Ibisomi L. Is age difference between partners associated with contraceptive use among married couples in Nigeria? Int Perspect Sex Reprod Health 2014; 40(1): 39-45.

[http://dx.doi.org/10.1363/4003914] [PMID: 24733060]

[45] Harris AD, McGregor JC, Perencevich EN, et al. The use and interpretation of quasi-experimental studies in medical informatics. J Am Med Inform Assoc 2006; 13(1): 16-23.

[http://dx.doi.org/10.1197/jamia.M1749] [PMID: 16221933]

[46] Ronay R, Kim DY. Gender differences in explicit and implicit risk attitudes: a socially facilitated phenomenon. Br J Soc Psychol 2006; 45(Pt 2): 397-419.

[http://dx.doi.org/10.1348/014466605X66420] [PMID: 16762107]

[47] Wallach MA, Kogan N, Bem DJ. Diffusion of responsibility and level of risk taking in groups. J Abnorm Psychol 1964; 68: 263-74. [PMID: 14126840]

[48] Freedman K. Effects of collaboration on grade retention decision making. Master of Science Thesis, Department of Educational Psychology and Learning Systems, Florida State University. 2007.

[49] Nunnally JC, Bernstein IH. Psychometric theory. 3rd ed. NewYork: McGraw Hill 1994.

[50] Howell D. Statistical methods for social psychology Duxbury. Pacific Grove, CA: Duxbury/Thomson Learning 2002.

[51] Defoe IN, Dubas JS, Figner B, van Aken MA. A meta-analysis on age differences in risky decision making: adolescents versus children and adults. Psychol Bull 2015; 141(1): 48-84 [http://dx.doi.org/10.1037/a0038088] [PMID: 25365761]

(C) 2020 Peter J.O. Aloka.

This is an open access article distributed under the terms of the Creative Commons Attribution 4.0 International Public License (CC-BY 4.0), a copy of which is available at: (https://creativecommons.org/licenses/by/4.0/legalcode). This license permits unrestricted use, distribution, and reproduction in any medium, provided the original author and source are credited. 